\title{
Lean Leadership as a Tool to Minimize the Impact of Uncertainty on Individual and \\ Organizational Attitudes and Behaviour: A Meta-Analysis \\ Dr. Jameel Zuhair Kutbi \\ Assistant Professor of Industrial Engineering Head of HRM Department, College of Business \\ University of Jeddah \\ Kingdom of Saudi Arabia
}

\begin{abstract}
A quantitative review of the literature (meat-analysis) was conducted with 36 studies which focuses on Lean Leadership. Studies issued between 1972 and 2017 were included in the review with the focus of Lean Behaviours. The overall need for this school of management had been reconfirmed with this sample of studies. Implications for this research will increase opportunities for successful organisational transformation. Despite the importance of leadership in organisational transformation, few researchers explored lean leadership in times of uncertainty and how this will affect transformational initiatives. The purpose of this paper is to provide insights into applicable behaviours and attributes for lean leaders during economic turbulence. Various conclusions and recommendations were highlighted to improve lean leader's effectiveness.
\end{abstract}

Keywords: Lean Leadership, Uncertainty, Lean Culture, Motivation, Lean Behaviour, systematic Transformation.

\section{Introduction}

"Leadership is the art of accomplishing more than the science of management says is possible"

Colin Powell

There is no question that the harsh reality of a severe economic downturn is still affecting many countries all over the world, it is 18 years since the infamous words "Credit crunch" became the standard vernacular at most gatherings. One has only got to look at the spending cuts in Saudi Arabia and the meltdown of economies like Spain, Ireland, UK, USA to realize that we face levels of uncertainty in the region not seen since the Gulf war in 1990.

Given the likelihood of deep public spending cuts, the only engine of true growth will be the manufacturing sector. In order to engineer this growth, significant Lean transformations and reinvigorations in organizations will be required to eliminate waste and create value from their current asset base. Successful lean transformation always involves changes in an organization's structure and in an organization's culture, which is made up of its people's values and beliefs (Rother, 2010). In the current economic climate these are being challenged both at the individual and the organizational level.

Strong Lean Leaders will be required to be the catalyst for change, there is the need to drive out fear and remove the barriers that prevent improvement and pride in his/her work. In this paper, we will discuss the

* This article was submitted in June 2018, and accepted for publishing in August 2018. 
framework for a successful lean transformation, the cultural shift required, the leadership characteristics and systems thinking paradigm that will enable such a change. As a precursor to this it is imperative to have an appreciation of what influences attitudes and behaviors, what motivates us, and in times of great uncertainty what is the required DNA make-up of a good Lean Leader.

\section{Section.1 Behaviours and Motivation}

The approach first introduced by Trist and Bamforth of the Tavistock Instititute was based on the premise that an organization is simultaneously a social and a technical system (Beckhard, 2006). The technology is tangible, you can touch it, it is easy to visualize. All organizations are also made up of people who interact to perform a series of tasks, this human dimension makes up the social subsystem, which is intangible but essential to understand in order to effect change.

This human dimension is governed by behaviours which are driven by either an individuals or organization motivation. There have been several theories put forward by behavioral scientists on behaviours and motivation which are summarized in (Table 1). In addition, these theories can be classified against what they are striving to address, be it algorithmic/system requirements against the backdrop of the individual or the organization, this is summarized in the Weisbord Framework (Weisbord,1976) in (Fig.1).

\section{Table (1): Motivation Theories}

\begin{tabular}{ll}
\hline Theory & Main Principles \\
\hline Maslow's Hierarchy & Physiological, safety, social, esteem, self actualization \\
\hline Theory X and Theory Y - & $\begin{array}{l}\text { X-Employees dislike work, must be coerced, Teflon shoulders, place security first. } \\
\text { Y- Work is natural, committed to the role, self directed, seek responsibility, creative }\end{array}$ \\
\hline McGregor & $\begin{array}{l}\text { Hygiene factors affect job - supervision pay, work conditions, job security } \\
\text { Motivator factors affect satisfaction- promotion, recognition, responsibility } \\
\text { achievement }\end{array}$ \\
$\begin{array}{l}\text { Herzberg's Two Factor } \\
\text { Theory }\end{array}$ & $\begin{array}{l}\text { - Need at work } \\
\text { Theory of Needs - McClel- }\end{array}$ \\
land & - Need for Power \\
& - Need for affiliation \\
Goal Theory & $\begin{array}{l}\text { Intentions expressed as goals, can be major source of } \\
\text { motivation - more challenging the goal the higher the } \\
\text { higher the performance }\end{array}$ \\
\hline & $\begin{array}{l}\text { Attractiveness of the reward } \\
\text { Performance reward linkage } \\
\text { Expectancy Theory }\end{array}$ \\
\hline
\end{tabular}

Daniel Pink in his publication "Drive" categorizes motivation into four different buckets which are influenced by the environment we find ourselves in (Pink, 2009):

- Motivation 1: Do whatever it takes to survive -need to restrain this behaviour in a more complex society

- Motivation 2: Traction from 1900's - presumes that humans respond to rewards and punishments, they are extrinsically motivated, the carrot and stick effect. It could be argued that it was the over amplification of the carrot in the banking sector that created the current economic debacle (Van Vugt and Ahuja, 2010). Executives lent money they did not possess, which triggered significant bonuses in return; this continued to happen even as governments bailed them out with taxpayer's money.

- Motivation 3: Upgrade from Motivation 2 additional presumption that humans have a third drive to learn, to create and better the world.

Type I: Not driven by rewards and punishments, intrinsically motivated, powered by our own innate need to direct our own lives. 


\begin{tabular}{|c|c|c|c|}
\hline & Problems & Systems & Approaches \\
\hline Experts & $\begin{array}{l}1900 \\
\text { Experts Solve } \\
\text { problents }\end{array}$ & $\begin{array}{l}1965 \\
\text { Experts improve } \\
\text { whole systems }\end{array}$ & $\begin{array}{l}\text { Myers Briggs } \\
\text { Flow } \\
\text { TWI } \\
\text { Mintzberg }\end{array}$ \\
\hline Everybody & $\begin{array}{l}1950 \\
\text { Everybody solves } \\
\text { problems }\end{array}$ & $\begin{array}{l}2001 \\
\text { Everybody } \\
\text { improves whole } \\
\text { systems }\end{array}$ & $\begin{array}{l}\text { Tuckman } \\
\text { Likert's } 4 \text { stage } \\
\text { org theory } \\
\text { Audits, Belbin }\end{array}$ \\
\hline Approaches & $\begin{array}{l}\text { Ind Eng } \\
\text { OR } \\
\text { Six Sigma } \\
\text { A3 }\end{array}$ & $\begin{array}{l}\text { Systems Thinking } \\
\text { SSM }\end{array}$ & \\
\hline
\end{tabular}

Source: Weisbord, M. R. (1976). “Organizational Diagnosis: Six Places to Look for Trouble With or Without a Theory”, Group \& Organization Studies, 1 (4), pp. 430-447.

Fig.1: Weisbord Model

Motivation 2 does not work but is still widely practiced in Industry today (Pink, 2009). Contingent rewards have negative effects and may work in the short term but not in the longer term, for example, if you pay your children to learn a particular subject, it destroys their long term interest in that subject. In my own experience, it produces an artificial spike in discretionary effort in the month of September as performance assessments are carried out in October, and then there is the inevitable fall back below the mean requirement for the other eleven months of the year. Pink argues that if the Baseline rewards in an organization are adequate, Type I individuals can drive significant change and improvements, which echoes Herzberg's two factor theory first aired in 1958. Pink's theory is illustrated in (Fig.2)

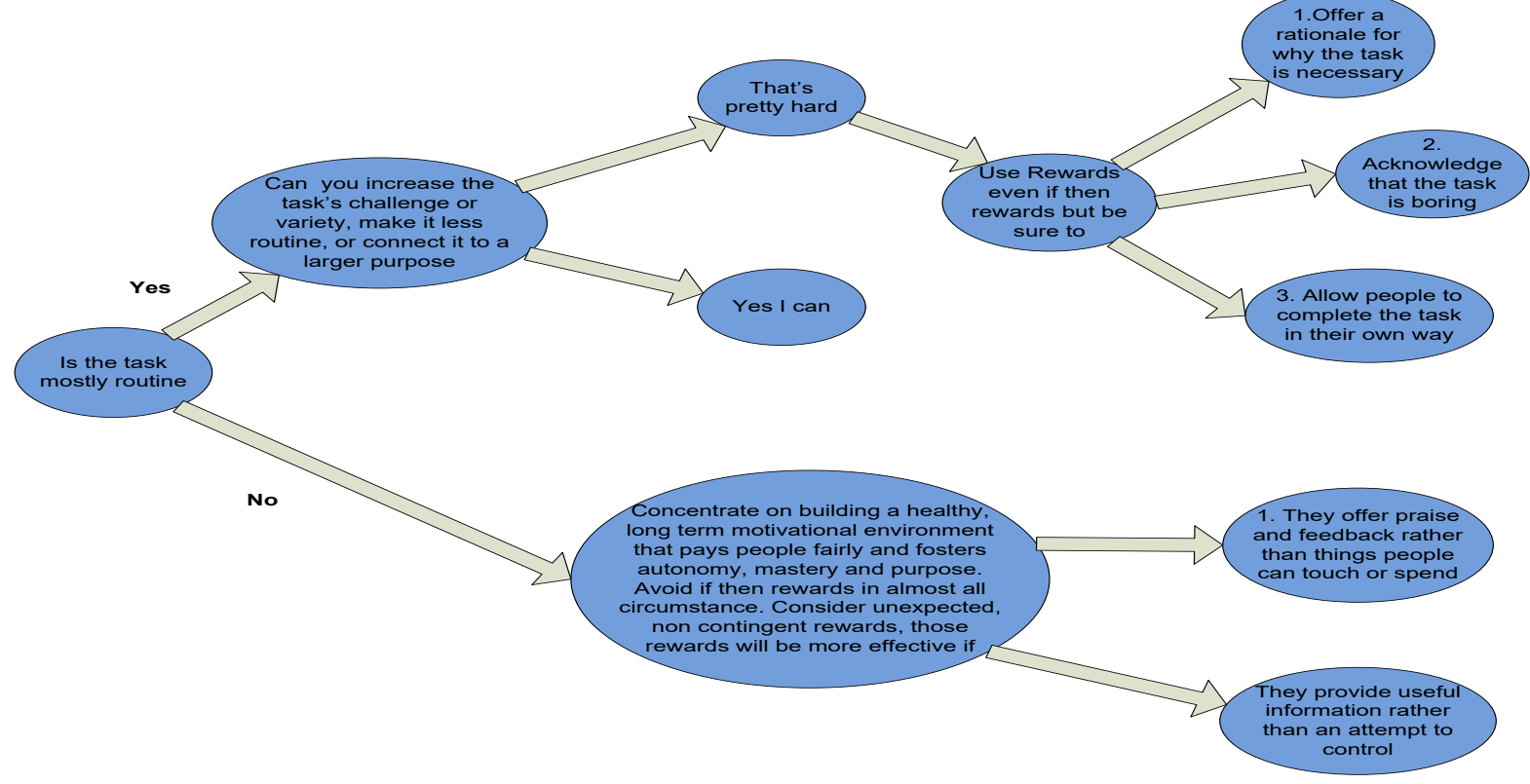

Source: Pink, D. H. (2009). Drive: The Surprising Truth about What Motivates Us. New York, NY: Riverhead Books.

Fig. 2: Motivation Flow Chart 
One of the central pillars of W. Edwards Deming's Theory of profound knowledge was the need to understand psychology and human behaviour. Understanding that people are different from one another, the focus should be on how to harness these differences in order to optimize everybody's abilities and inclinations. Deming advocated that corporations should focus on intrinsic motivation and not on extrinsic motivation, that self esteem is the most powerful propellant an organization can utilize (Deming,2000).

In our research for this paper the writings that best summed up the dichotomies that exist with the human brain in relation to our behaviours is an article entitled "The Nature of Man" co-authored by Jensen and Meckling (Jensen and Meckling, 1994). They propose 5 models of human behavior. Resourceful, Evaluative, Maximizing Model (REMM)

- Every individual care; he or she is an evaluator.

- Each individual's wants are unlimited.

- Each individual is a maximiser.

- The individual is resourceful.

REMM's cannot be satiated; they care about everything such as interpersonal relationships, status, group norms, and wealth. They are creative and open to change as it allows the opportunity to create changes. With REMM's there is no such thing as a need they are always willing to make trade-offs, they are always willing to give up a sufficiently small amount of any good for a sufficiently large amount of other goods.

\section{The Economic Model of Human Behaviour}

This model is a reductive version of the REMM, the person is an evaluator and maximizer but has only one want: Money, a pervasive behavior demonstrated by International bankers and property developers which lead to current banking crisis (Jensen and Meckling, 1994).

\section{The Sociological Model of Human Behaviour}

Individuals are viewed as a product of their cultural environment, they can be seen to be conformist and their behavior is determined by the customs and traditions by which they have been conditioned by. In society, they are the driving force behind teaching, learning and rewarding members of an organization or society. It could be argued that this type of behavior underpins the Toyota Production System (TPS) (Jensen and Meckling, 1994).

\section{The Psychological Model}

The best known embodiment of this model is provided by A.H.Maslow. He wrote "that human needs arrange themselves in hierarchies of prepotency" (Maslow 1943). Maslow's need in order of priority from high to low are physiological (food, water, shelter, and warmth), safety, love and self-actualization. (Jensen and Meckling, 1994)

\section{The Political Model}

The individual seeks to maximize "the public good" rather than his or her own welfare. They will adhere to the principal while if necessary denying their own. This model lies at the center of all campaigns that seek to solve problems by creating a government agency or appointing a political body, which usually become unwieldy and fail to deliver (Jensen and Meckling, 1994).

All these behaviours can be found through every layer in society, the one common denominator is that they are Individualistic (Goleman, 1998). Fig.3 illustrates organizational/individual independency model, that shows the impact of individual motivation on organizational motivation and vis-versa. The following section. 2 will explain how do these behaviours coalesce into leadership styles that show up in an organization? 


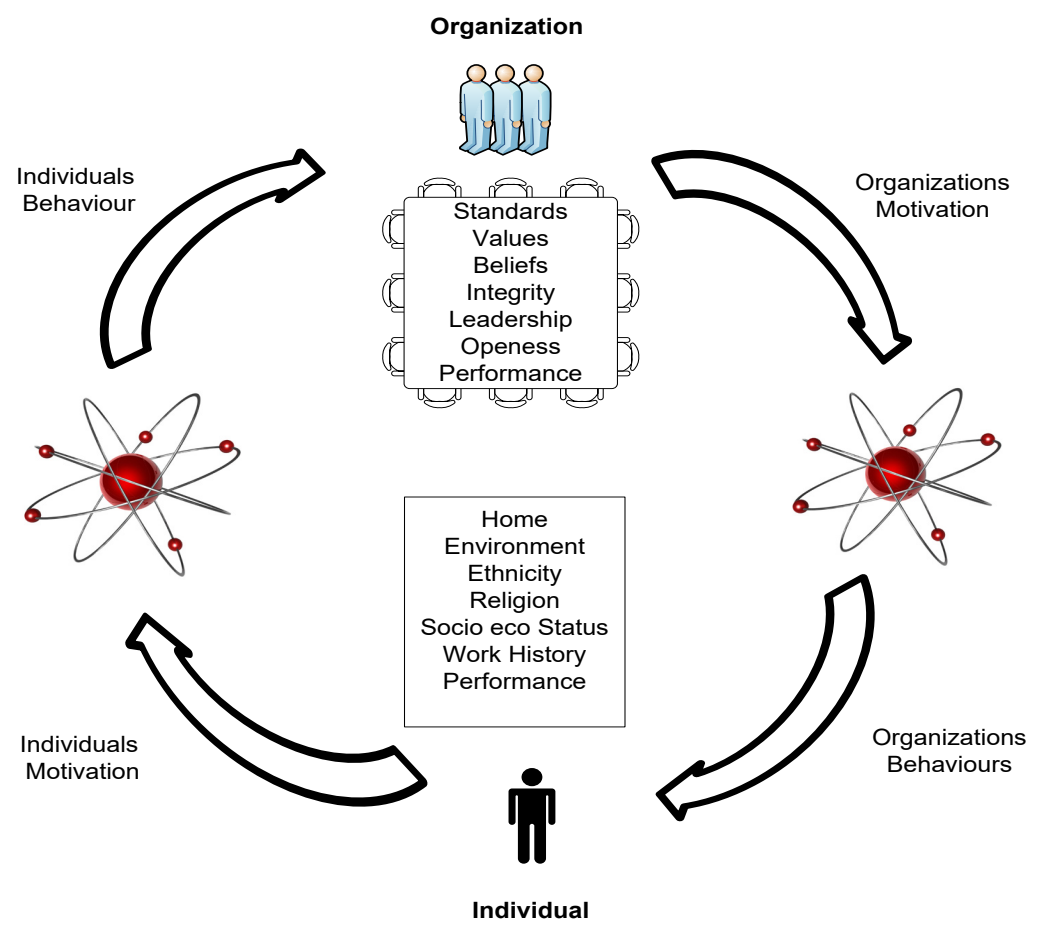

Source: Huczynski, A. and D. A. Buchanan (2010). Organizational Behaviour. Financial Times, Prentice Hall.

Fig. 3: Organization/Individual Interdependency Model

\section{Section 2 Leadership}

In order to ensure a successful Lean Transformation in an organization, it is critical that the Lean Leader has the support of the wider organization, which is made up invariably of a set of Leaders. It is a widely held view that their styles set the tone for any organization. In the book "Command and control" Seddon views the role of leadership as influencing based on knowledge and not hierarchical position (Seddon, 2003), which aligns with Deming's "System of profound knowledge". The converse of this exists in many organizations especially if they are chasing numbers to survive in the current climate.

As with Toyota Production System (TPS) with there has been a preoccupation over the centuries with the de-codifying of Leadership styles. Shackleton was hailed" As the greatest leader that ever came on God's earth, bar none," yet he never led a group bigger than twenty seven, he failed to achieve practically every goal he set, but through the account of his Antarctic expedition of 1914 - 1916 and the portraits offered to us by those under his command, portray a model of great leadership and in particular, a master of guidance in a crisis (Morrell and Capparell, 2001). Given the current economic crisis, a Lean Leader can learn from Shackleton's approach which can be summarised in the following points:

- Take the time to observe before acting, especially if you are new to the scene, all changes should be aimed at improvement, don't make changes just for the sake of change.

- Always keep your door open to your staff members and be generous with information that affects them. Well - informed employees are more eager and better prepared to participate.

- Establish order and routine on the job so all workers know where they stand and what is expected of them, discipline makes the staff feel that they are in capable hands.

- Breakdown traditional hierarchies and cliques by training workers to do a number of jobs, form the menial to the challenging.

- Where possible, have employees work together on certain tasks. It builds trust and respect and even friendship. 
- Be fair and impartial in meeting out compensation, workloads, and punishments. Imbalances make everyone feel uncomfortable, even the favored.

- Lead by example. Chip in sometimes to help with the work you're having others do. It gives you the opportunity to set a high standard and shows your respect for the job.

- Have regular gatherings to build esprit de corps. These could be informal lunches that allow workers to speak freely outside the office.

In their book "Selected" Van Vugt and Ahuja offer their perspective as to why some people lead, why others follow and why it matters (Van Vugt and Ahuja, 2010). In this process, they offer up several Leadership theories and even boil it down to Leaders primarily being driven by Sex, Salary and Status (Fig.4).

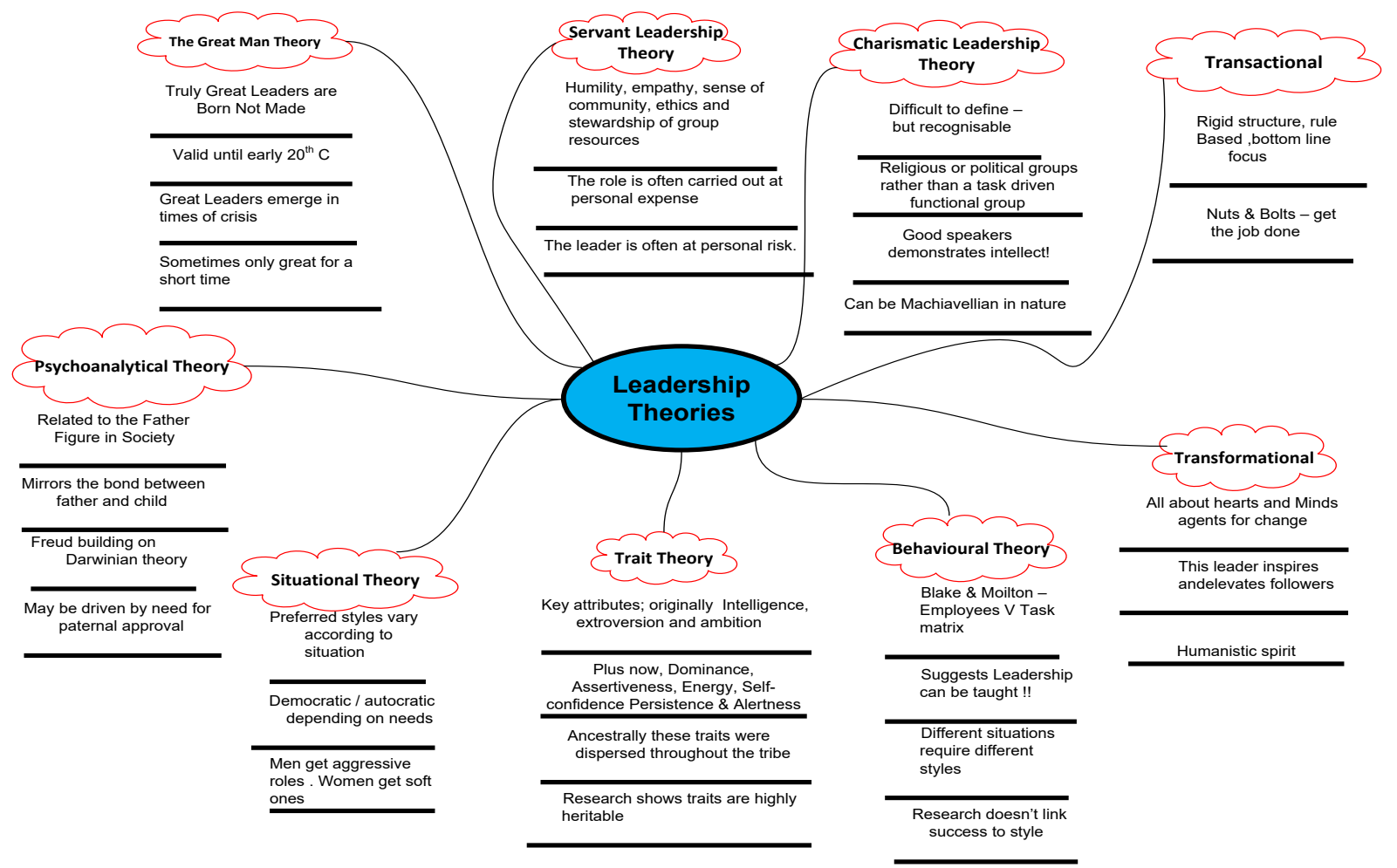

Source: Van Vugt, M. and Ahuja, A. (2010). Selected: Why Some People Lead, Why Others Follow, and Why It Matters. London: Profile Books.

Fig. 4: Leadership Theories

A paralyzed senior management team often arises from having too many managers and not enough Leaders (Kotter, 1996). Understanding the difference between Leadership and Managing is critical in enabling the momentum required to effect real change. The following (Table 2) and (Fig. 5) illustrate key differences between Leadership \& Management.

Irrespective of Leadership style it is also contended in some quarters (Goleman, 1998) that the most effective leaders have one common thread, they have a high quotient of emotional intelligence. Not being dismissive of IQ and technical skills, they can be seen as entry level requirements to the upper echelons of management, emotional Intelligence is the differentiator! (Goleman, 1998).

It is important not to ignore the arguments put forward that irrespective of the leadership style adopted in an organization, it's impact can be ambiguous in terms of the performance of a company (Pfeffer, 1977). Hall contends that the 3 reasons as to why the effects of Leaders on organizational outcomes would be small are firstly, those getting key leadership positions are selected and in some cases very narrow styles of behaviour are chosen, often mirroring the behaviours of the selectors - a former colleague of my coined this as the "yes man syndrome". Second, once in the position, the discretion and behaviour of the leader 
are constrained by the hiring handcuffs. Thirdly, Leaders can typically affect only a few of the variables that actually impact an organizations performance (Hall, 1972).

In summary, there are many styles of leadership witnessed both in the corporate boardroom and the shop floor and whilst certain styles of Leadership behaviours can deliver huge dividends, the absence of any leadership or failed leadership is the biggest crime of all as stated by (Hines et al., 2008) in (Fig.6).

Table (2): Leaders vs Managers

\begin{tabular}{cc}
\hline Leaders & Managers \\
\hline Innovates & Administers \\
\hline Is an Original & Is a Copy \\
\hline Develops & Maintains \\
\hline Focuses on People & Focuses on system and structure \\
\hline Inspires Trust & Relies on Control \\
\hline Has a long-range perspective & Has a short-range view \\
\hline Ask Why & Asks how and when \\
\hline Has eyes on the horizon & Has his eyes on the bottom line \\
\hline Originates & Imitates \\
\hline Challenges the status quo & Accepts the status quo \\
\hline Source: Hines, P.; Found, P.; Griffiths, G. and Harrison, R. (2008). Staying Lean: Thriving, Not Just Surviving. Cardiff, Lean Enterprise Research Centre.
\end{tabular}

Leaders vs Managers

Source: Collins, J. C. and Porras, J. I. (2005). Built to Last: Successful Habits of Visionary Companies. Random House.

Fig. 5 Leaders vs Managers
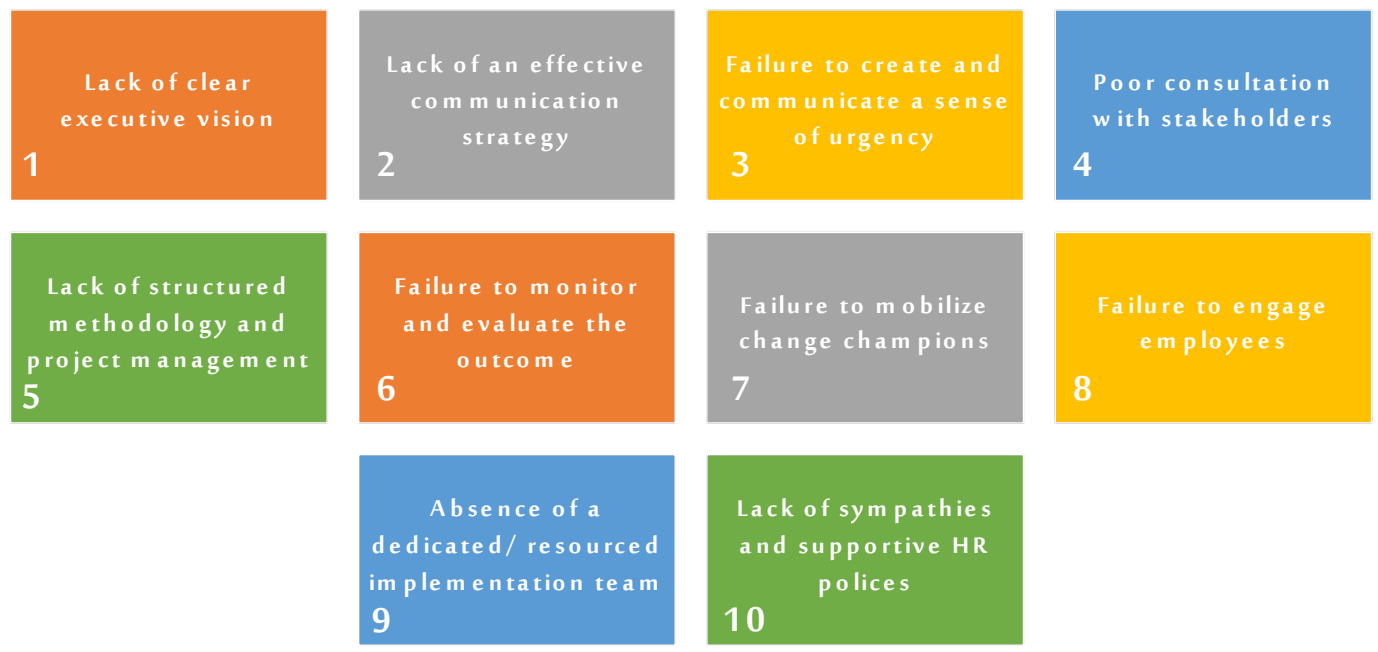

Source: Hines, P.; Found, P.; Griffiths, G. and Harrison, R. (2008). Staying Lean: Thriving, Not Just Surviving. Cardiff, Lean Enterprise Research Centre.

\section{Fig. 6: Leadership Failure}




\section{Section. 3 The Lean Leader}

Having discussed what motivates individuals and explored different leadership styles, this is where we lay our cards on the table; we firmly believe that a Lean Leader needs to have a Transformational leadership style with a Tayloristic twist. Every text book on lean proclaims that a burning platform is required to enable a successful lean program; this has been provided by the extrinsic motivation of our financial sector. Given the likely fear and apathy they will face given the current economic background, the Lean leader the needs to be Transformational. This occurs when they elevate the interests of their employees, when they generate awareness and acceptance of the vision and engage the employees to a such an extent that they look beyond their own self interest and deliver an extraordinary level of discretionary effort and transcend into the category of the follower (Bass, 1990).

Transformational leadership is best suited to selling a strategic vision for change and for this to be truly representative of the needs of the organization the Lean leader must have a systems thinking approach (Vera and Crossan, 2004). Deming in his book "The New Economics" defines a system as "a network of interdependent components that work together to try to accomplish the aim of the system".

\section{Culture}

One of these interdependent parts of an organization is culture (Fig.7), to effect significant levels of change it is imperative that an open and trusting culture is created that permeates every level of the organization where a feeling of we are all in this together is created. In section 4 we will discuss further the possible intervention methods that can be used to create the cultural shift that will be necessary to deliver a lean transformation.

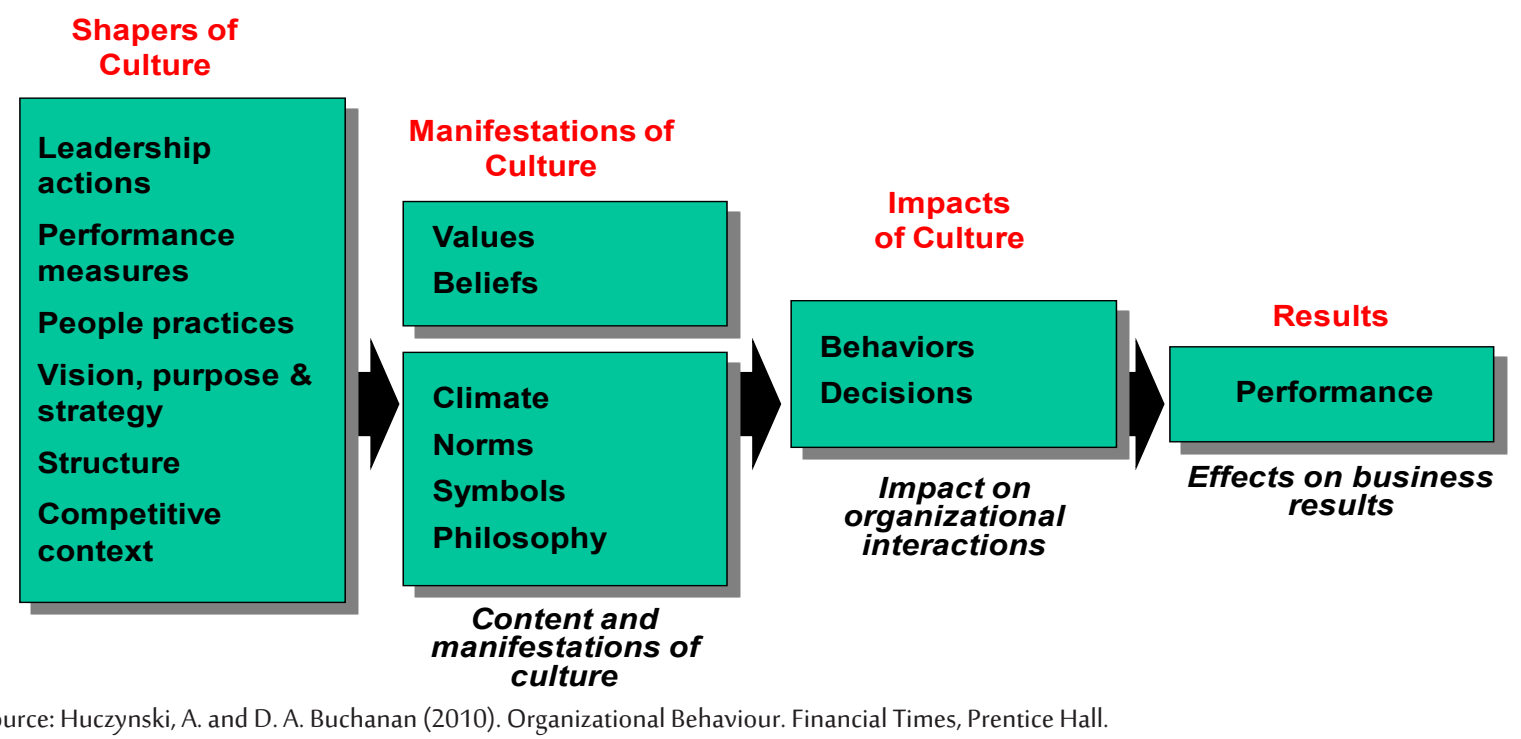

Fig.7: Effects of Culture on Performance

It is advisable that the Lean leader needed to be transformational in style but Tayloristic in delivery. Taylor in the early $19^{\text {th }}$ century was an advocate of scientific management and disciplined work methods. It is essential that alongside the inspirational dimension there is a disciplined Lean/change management approach. The Lean Leader has to, in parallel with creating the cultural critical mass for change, adopt a lean thinking approach, creating a plan, installing the basic foundations for Lean - from 5's/TPM /Standard Work/TWI/Kaizen events through to mapping, the removal of Muda, Muri and Mura and establishing flow through the system.

Complementing this is the need for the wider organization at the highest level to support this transformation through its Policy deployment which should lay out the strategic path covering the next 1 to 5 years 
highlighting the critical success factors along the way (Hines et al., 2008). In times of economic uncertainty Hoshin Kanri is vital to providing hope to those working at the coal face. Mann advocates a disciplined approach by a Lean Leader to role model the expectations (Mann, 2009):

- Leader Standard work: checklist is created to standardize a portion of a Team Leaders or Manager's day to ensure the critical elements of their job is performed.

- Visual Controls: allows the leader to monitor performance in an area while on a Gemba.

- Daily accountability process: acting on the feedback from the visual controls, ensuring corrective actions are taken for processes that go out of control.

- Leadership discipline: adherence to standard work, ensuring the integrity of the process.

Additionally, Rother in his famous book "Toyota Kata" reinforces the argument for routine, puts forward that a kata (routine) is a means for keeping your thoughts and actions in sync when faced with dynamic and uncertain conditions (Rother, 2010). By adopting a routine for improvement and coaching, transformations become a daily occurrence as witnessed at Toyota, an integral part of the TPS DNA and can be dated back to the adoption of Training within Industry techniques post World War 2. Moreover, Rother \& Aulinger proposed a four-step model or "pattern of scientific thinking and working", this improvement Kata is a meta skill that is useful at every level of an organization. Eventually, a living organizational system will be created which adapts, innovate, and continuously improve (Rother \& Aulinger, 2017).

Moreover, there are several change models developed that can be used to good effect in to ensure a structured approach, in particular Kotter's Eight steps to Transforming your organization (Kotter, 1996) (Fig. 8) and Kanter's Ten Commandments in particular stand out for me (Kanter et al., 1992) (Fig. 9).

Specific to Lean transformations, Rother in his book "Learning to see" calls out five mistakes often made when implementing Lean (Rother, 2010)

- Do not confuse techniques with objectives.

- $\quad$ Expect training to make Lean happen.

- Leading from the office - mot embracing Gemba.

- Relying solely on Blitz workshops.

- Quitting after failures or to early.

\section{KOTTER'S 8 STEP CHANGE MODEL}

8 Steps for Leading Change

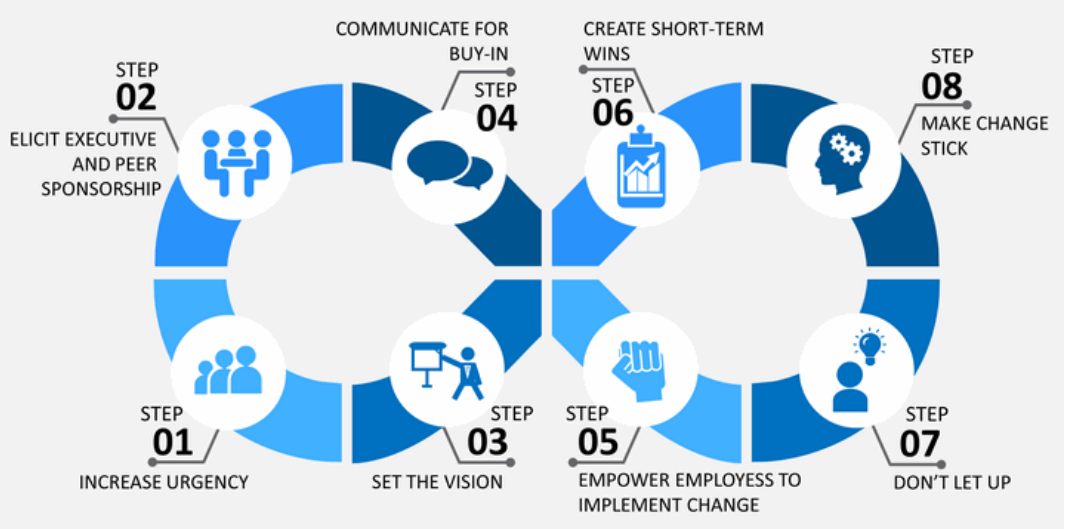

Source: Kotter, J. P. (1996). Leading Change. Boston Mass: Harvard Business School Press.

Fig. 8 Kotter's Eight Step Model 


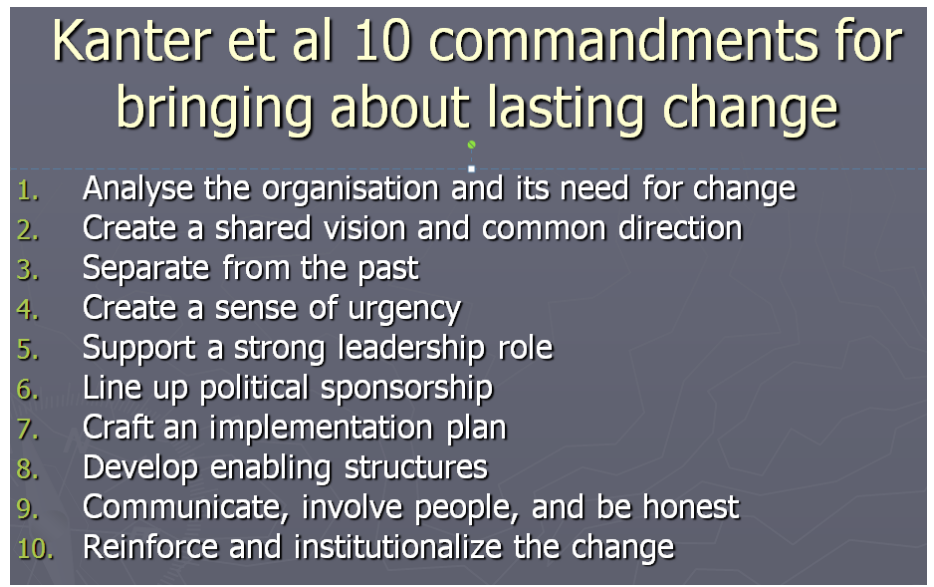

Source: Kanter, R. M.; Stein, B. A. and Jick, T. D. (1992). The Challenge of Organizational Change in The Free Press. New York.

\section{Fig.9 Kanter's Ten Commandments}

Another watch out, for the Lean Leader is to be wary of the "Halo effect" (Rosenzweig, 2007) where there is a tendency to look at a company's performance through rose tinted glasses when performance is good and making the immediate conclusion that the culture and leadership is fantastic and the exact opposite when the company's performance is poor - there must be an issue with the leadership and the culture.

A great example of the Halo effect can be seen weekly on the TV program "The Apprentice" BBC at the UK. The team asked by Lord Sugar as to how the Team Leader performed, prior to the Team Leader picking the 2 team members who he wants to take back it to the boardroom, the team invariably say he/she was great, but when they loose and face getting fired, the team members suddenly have a change of mind, saying that his/her leadership style was the reason they lost the task.

\section{NUMMI}

An excellent example for a Lean Leader chronicled by John Shook where significant change was brought about through cultural change is the NUMMI plant. NUMMI was set up as a joint venture between GM and Toyota in 1983, It was Toyota's first steps into manufacturing in the US. They partnered with the worst performing GM plant in Fremont with a malcontent workforce, absenteeism running at $20 \%$ and the worst quality in the GM group (Shook, 2010). Within a year it became GM's best plant in terms of quality and absenteeism was down to $2 \%$, all achieved with the same workforce (Shook, 2010), how was this achieved?. The only things to change were the management system and somehow the culture. Key tenants to changing the culture were (Shook, 2010)

- Give workers the means to successfully carry out their jobs - and on system - build in quality.

- Creating an environment for continuous learning.

- Building mutual trust and respect - layoffs a last resort.

- Production floor leaders involved in hiring their own team members.

- No layoffs as a result of a Kaizen event.

Shook based on this experience maintains that to change a culture you should not focus firstly on how people think, but begin by changing how people behave and in particular the Lean Leader needs to recognize that "It's easier to act your way into a new way of thinking than to think your way into a new way of acting" (Shook, 2010) (Fig.10). 


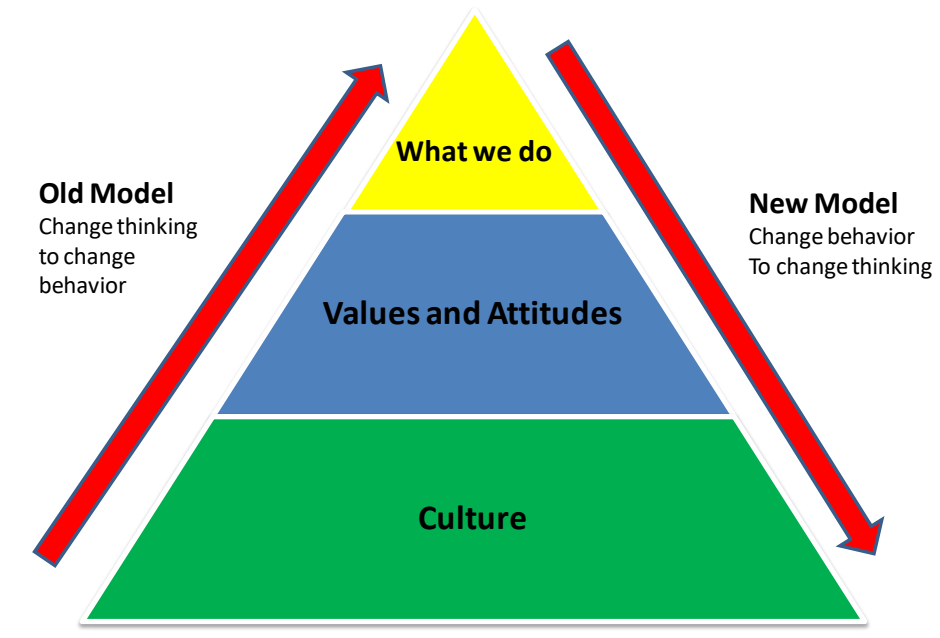

Source: Shook, J. (2010). “How to Change a Culture: Lessons From NUMMI”, MIT Sloan Management Review, 51.

Fig. 10: Influence culture change- Shook's Version

\section{Section 4- Transforming the culture through positive Intervention}

The author discussed the necessary requirement for the Lean Leader to have a disciplined, Tayloristic spine, but this is more required for the implementation phase. The question is how the Transformational Leader wins the hearts and minds of the employees at the outset to release the handbrake on the juggernaut of change especially given the potential fear and apathy that has been created by events out with their control.

First requirement is to understand the organizations dynamics according to (Devine, 2011), is recognizing that every employee has their own psychological filter (values \& beliefs) which they see they see the world through, built up over many years of repetition, referred to as the Pygmalion effect (Eden,1990) (Fig. 11). The Lean Leader needs to be conscious of this from the outset.

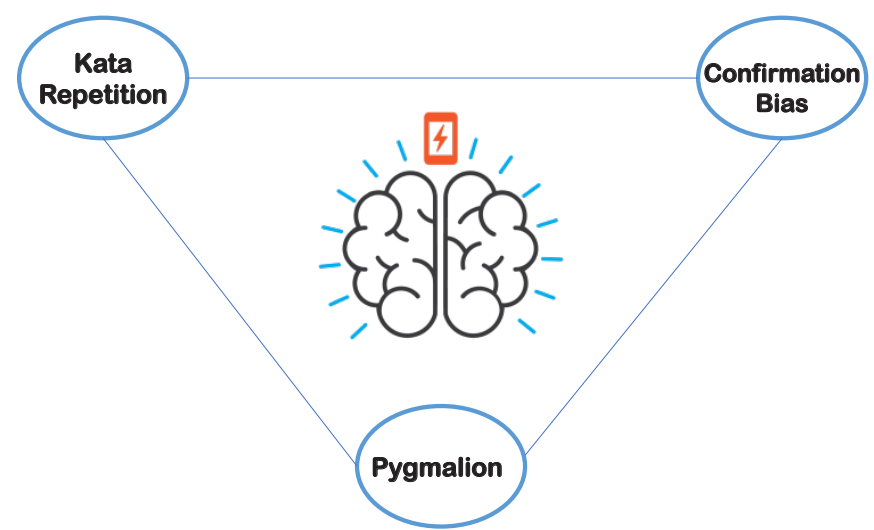

Source: Eden, D. (1990). Pygmalion in Management: Productivity as a Self-fulfilling Prophecy. Lexington Books/DC Heath and Com.

\section{Fig.11: Pygmalion effect}

Second, there is likely to be four different modes of behaviour that you will be confronted with (Eden,1990):

- Victim: Why me?

- Critic: It will never work!

- Bystander: adopts the wait and see approach, needs greatest caution

- Navigator: adjusts well to new situations, sees opportunities 
It is important to deal with each one of these groups with equal importance, because if you dismiss the minority opinion at the start it will be detrimental to the outcome. If we deny life's need to create, life will push back, this is typically seen as resistance to change and we create strategies to overcome it (Wheatley, 2005), we would be far better employed if we learned how to harness the resident creativity in our companies, we must work with these creative forces or they will be provoked to work against us. The approach taken by the Lean Leader in dealing with conflict will inevitably arise; can often determine the success or failure of the program. The six styles of dealing with conflict is summarized according to (Kerzner, 2009) in (Table 3).

\section{Table (3): Approaches to Conflict}

\begin{tabular}{|c|c|}
\hline Style & Description \\
\hline Avoiding & Retreats from actual or potential conflict situation \\
\hline Accommodating & Emphasizes area of agreement rather than areas of difference \\
\hline Compromising & $\begin{array}{l}\text { Searches and bargains for solutions that brings a degree of satis- } \\
\text { faction to all parties }\end{array}$ \\
\hline Forcing & $\begin{array}{l}\text { Pushes one view point at the expense of others, offers only win- } \\
\text { lose solutions }\end{array}$ \\
\hline Collaborating & $\begin{array}{l}\text { Incorporates multiple viewpoints and insights, leads to consensus } \\
\text { and commitment }\end{array}$ \\
\hline Confronting & $\begin{array}{l}\text { Treats conflict as a problem to be solved by examining alterna- } \\
\text { tives, requires give and take open dialogue }\end{array}$ \\
\hline
\end{tabular}

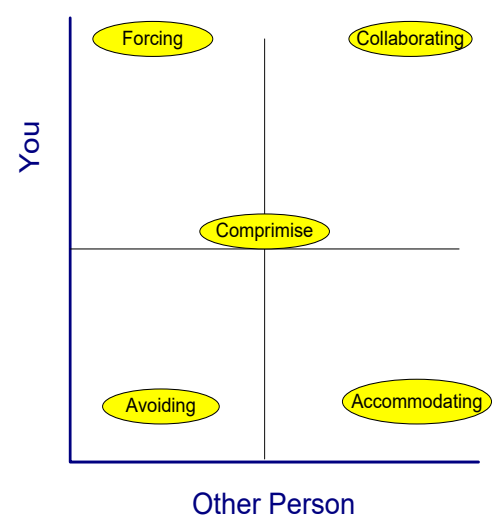

Source: Kerzner, H. (2009). Project Management: A Systems Approach to Planning, Scheduling, and Controlling. Hoboken, N. J., John Wiley \& Sons.

In his book "Tipping Point" Gladwell contends that in terms of dynamics it is important to identify who are the (Gladwell, 2002):

- Mavens: knowledge accumulators (they like to help)

- Connectors: know everyone, well networked

- Salesmen: persuaders

The following is invaluable for Lean Leaders when they are negotiating the conditions for change:

\section{Trust and Integrity}

The Lean Leader must build an atmosphere where they are viewed with integrity and trust is established out of the blocks. As we move into more transparent and equally suspicious working environment trust will be the enabler for converting the Critics, Victims and Bystanders into Navigators. Low Trust causes friction, it is the greatest cost in organizations, it creates hidden agendas, politics, interpersonal conflict, winlose thinking and protective communication (Covey and Merrill, 2006). Trust is the catalyst for any cultural revolution, trust turns strangers into friends and then partners (G.A.Howell et al., 2004).

\section{The Mechanics of Intervention and Engagement}

There are a number of approaches that can be used to instigate cultural change. Firstly, the engagement model advocated by Frank Devine, a case study reflecting on a successful Lean introduction program at a European company showcases this approach. Three workshops were set up in sequence, the first workshop was with the senior team to get full commitment and alignment on the scope, the second workshop was held with the senior team and middle managers, for them to work through the issues and get them aligned to the compelling need.

The third workshop was held with Senior Team, Middle Management, and the key Trade Union representatives, where the focus was on creating the right environment for change establishing the values and beliefs that would be the bedrock for success. Having the trade union representatives involved with the de- 
sign of the new system enhanced the mood for collaboration and reduced the barriers of engagement with the employees. This forms the foundation of Devine's Cathedral Model (Devine, 2015) (Fig.12).

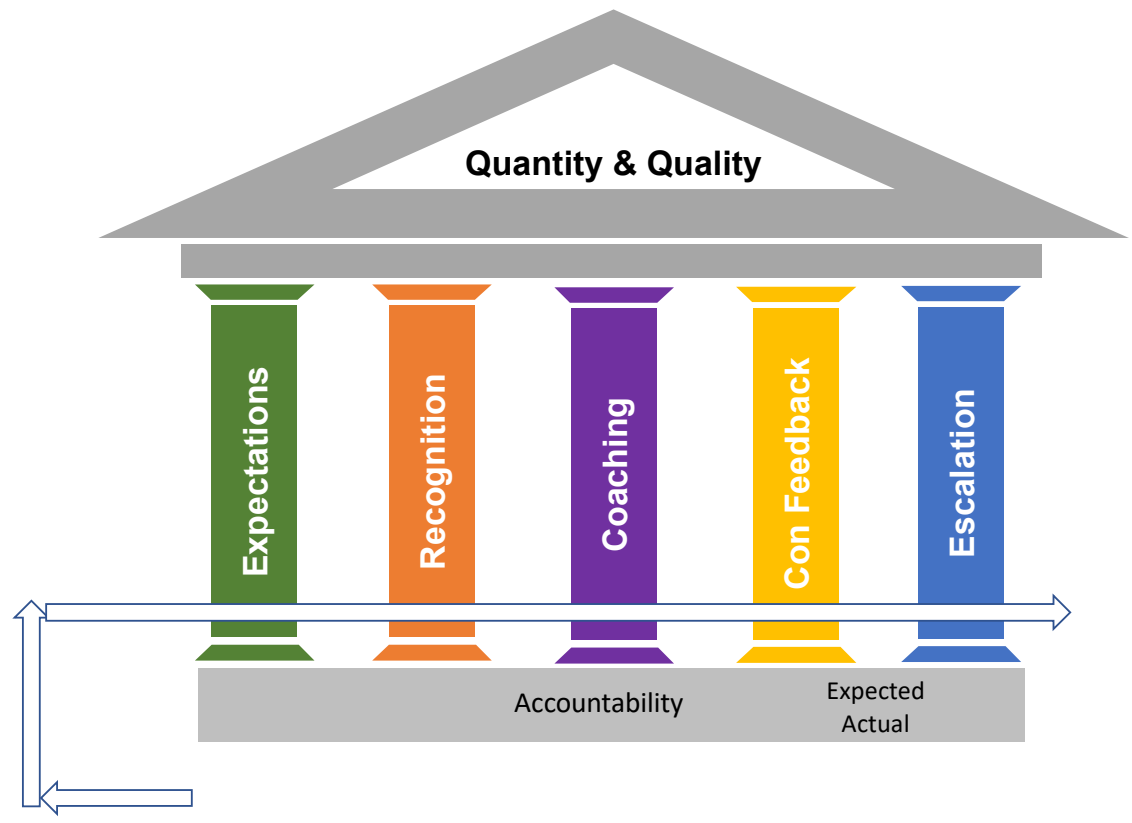

Source: Devine, F. (2015). Demystifying Leadership: Setting Leaders Up For Success - ICBE [online]. Avliable at: http://icbe.ie/wpcontent/uploads/20152/11/_ Frank_Devine_Demystifying_Leadership.pdf [Accessed: 6 April 2018].

\section{Fig.12: Cathedral Model}

The approach taken to the intervention process influences significantly the outcome. Two common mistakes are often made, firstly: naïve engagement; where management hope by giving autonomy to the employees it will naturally result in improvement. Secondly: timid engagement; where employees are given involvement in trivial decisions like, what color should we paint the canteen, they will see straight through this. It is also necessary to have a clear communication strategy predetermined to maximize the message absorption process within in the company (Fig.13).

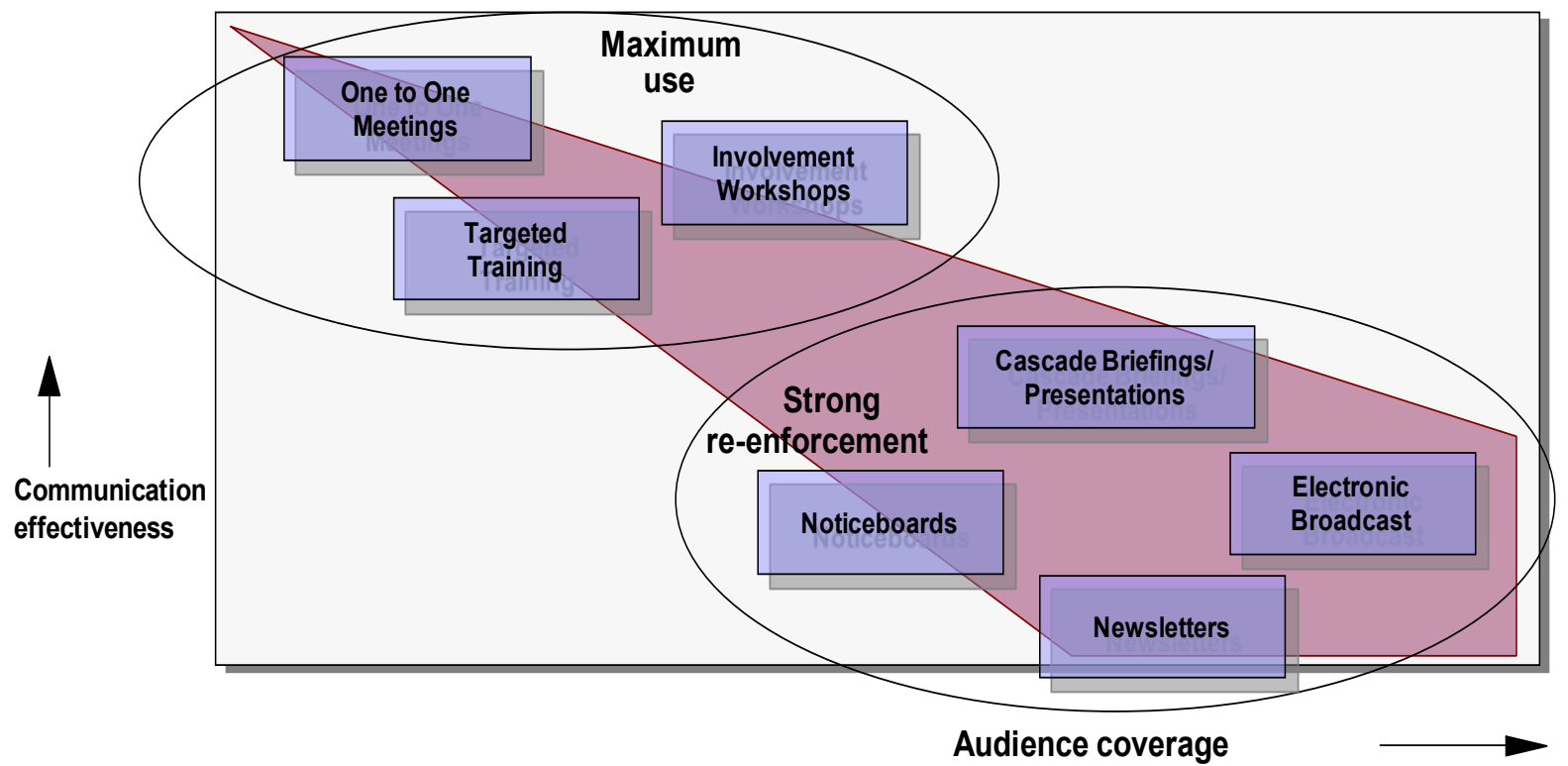

IBCT (International Board of Certified Trainers). (2016). Coach Trainer Programme. Netherland.

Fig.13: Communication Strategy (IBCT CT Programme) 
In the face to face engagement with employees a number of different styles can be employed, but will only bear fruit in an atmosphere of integrity and trust. Devine advises the following approach (Devine,2015)

- Empathy acknowledgement - acknowledge their emotional reaction

- Reasonable response acknowledgement

- Neutral acknowledgement - Playback what they have just said.

An employee paraphrased this approach as "seek first to understand, then to be understood"

Another style of engagement that is becoming popular is "Appreciative Inquiry" (Holman et al., 2007), it is founded on the cooperative search for the best in people, their organization and the world around them. It involves the use of questioning techniques that focuses on the positive potential of the individual and the organization (Sue.A.Hammond, 1998) (Fig.14).

Recently it has started to become an Industry standard to electronically survey the pulse of an organization especially leading up to a significant change, often termed "engagement surveys", a supposedly well-crafted set of questions that will give management the inside track. We caution against the use of these tools, it does not foster the humanistic spirit, Deming and Greenleaf were strident in their beliefs that we are servants to the human spirit and it is our responsibility to nurture that spirit (Wheatley, 2005).

In our own experience, we have seen these types of surveys promote the wrong behaviors, a number of years ago a manufacturing site at the western region in Saudi Arabia was at the bottom of the league in terms of the "Credo survey", which monitors annually the culture or the Organization, when these results started to be used as a tie breaker in awarding new business to manufacturing sites in different regions, there was a seismic shift in their results. In a period of 1 year, they went to the top of the table, held up as the bastion of cultural excellence and change. When in fact there were no significant changes just the old motivation kicking in of "survival of the fittest".

\section{Appreciative Inquiry}

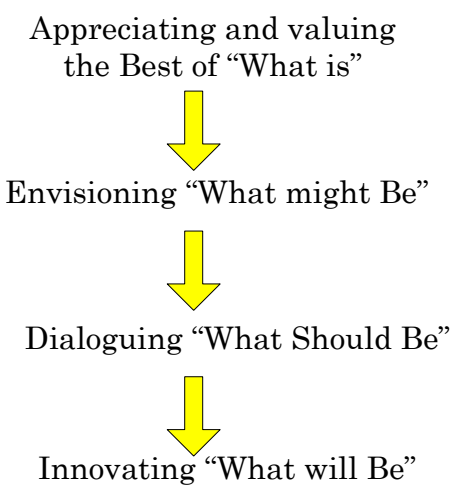

Source: Holman, P.; Devane, T. and Cady, S. (2007). The Change Handbook: The Definitive Resource on Today's Best Methods for Engaging Whole Systems. San Francisco, Berrett-Koehler.

Fig. 14: Appreciative Inquiry

\section{Conclusion}

In this research, we have reviewed and discussed what the Lean Leader may face in terms of motivations and behaviours of both the individual and the organization in this time of great economic uncertainty. How they need to have a Tayloristic spine in their implementation of the Lean framework, the hard yards 
of 5S, standard work, TWI, TPM, mapping and understanding the supply chain dynamics to mention a few need to be done.

This taken as a given, the Lean Leader needs to be Transformational in style, and they need to face the uncertainty of today's world with hope and trust in the near future. Additionally, they need to inspire through clarity of vision and an inner belief in there and their people's ability to generate change that brings real benefits to the business and the stakeholders. Real leaders face challenges, difficulties and sacrifices as well as opportunities with empathy and compassion for the people they lead and those they serve. They require what Deming called a 'constancy of purpose' and persistence in the face of adversity.

Big changes are taking place in Saudi Arabia's economy, and true Lean leaders will turn current challenges into opportunities that will flourish in the near future and contributes to Saudi's GDP. The whole country is being restructured and this requires a systematic cultural change on both public and privet sector, and the only way to accomplish 2030 goals is by going "Lean" and using its tools and methodologies where appropriate. 


\section{References}

- $\quad$ BASS, B. M. (1990). "From Transactional to Transformational Leadership: Learning to See the Vision", Organisational Dynamics [Online]. Available: papers.econ.mpg.de.

- Beckhard, R. F. (2006). "What is Organisational Development", Organisational Development. San Francisco, CA: Jossey-Bass.

- $\quad$ Boyatzis, R. E. and Mckee, A. (2005). Resonant Leadership: Renewing Yourself and Connecting with Others Through Mindfulness, Hope and Compassion. Boston: Harvard Business School Press.

- Collins, J. C. and Porras, J. I. (2005). Built to Last: Successful Habits of Visionary Companies. Random House.

- Covey, S. M. R. and Merrill, R. R. (2006). The Speed of Trust : The One Thing That Changes Everything. New York: Free Press.

- Deming, W. E. (2000). Out of the Crisis. MIT Press

- Devine, F. (2015). Demystifying Leadership: Setting Leaders Up For Success - ICBE [online]. Avliable at: http://icbe.ie/wpcontent/uploads/2015/11/2_Frank_Devine_Demystifying_Leadership. pdf [Accessed: 6 April 2018].

- Eden, D. (1990). Pygmalion in Management: Productivity as a Self-fulfilling Prophecy. Lexington Books/DC Heath and Com.

- Howell, G. A. ; H. Macomber; L. Koskela and J. Draper. (2004). "Leadership and Project Management : Time for a Shift from Fayol to Flores", In: 12th Annual Meeting of the International Lean Constructoin Network, Denmark.

- Gladwell, M. (2002). The Tipping Point: How Little Things Can Make a Big Difference, Boston, Back Bay Books.

- Goleman, D. (1998). "What Makes a Leader?” Harvard Business Review, 76, 93-102.

- Hall, R. H. (1972). Organizations: Structure and Process. Englewood Cliffs, N. J., Prentice-Hall.

- Hines, P.; Found, P.; Griffiths, G. and Harrison, R. (2008). Staying Lean: Thriving, Not Just Surviving. Cardiff, Lean Enterprise Research Centre.

- Holman, P.; Devane, T. and Cady, S. (2007). The Change Handbook: The Definitive Resource on Today's Best Methods for Engaging Whole Systems. San Francisco, Berrett-Koehler.

- Huczynski, A. and Buchanan, D. A. (2010). Organizational Behaviour. Financial Times, Prentice Hall.

- $\quad$ IBCT (International Board of Certified Trainers). (2016). Coach Trainer Programme. Netherland.

- Jensen, M. C. and Meckling, W. H. (1994). "The Nature of Man", Journal of Applied Corporate Finance. Vol. 7, Issue 2.

- Kanter, R. M.; Stein, B. A. and Jick, T. D. (1992). The Challenge of Organizational Change in The Free Press. New York.

- Kerzner, H. (2009). Project Management: A Systems Approach to Planning, Scheduling, and Controlling. Hoboken, N. J., John Wiley \& Sons.

- Kotter, J. P. (1996). Leading Change. Boston Mass: Harvard Business School Press.

- Mann, D. (2009). "The Missing Link: Lean Leadership", Frontiers of Health Services Management, Vol. 26, No. 1, p.15.

- Martin, R. J. (2018). Summary of The New Economics for Industry, Government \& Education. Available: http://maawinfo/ArticleSummaries/ArtSumDeming93htm [Accessed: 6 April 2018].

- Maslow, A. H. (1943). "A Theory of Human Motivation", Psychological Review, 50 (4), p. 370. 
- Morrell, M. and Capparell, S. (2001). Shackleton's Way: Leadership Lessons From the Great Antarctic Explorer, New York, Viking.

- Pfferr, J. 1977. "The Ambiguity of Leadership", Academy of Management Review, 12.

- Pink, D. H. (2009). Drive: The Surprising Truth about What Motivates Us. New York, NY: Riverhead Books.

- $\quad$ Rosenzweig, P. M. (2007). The Halo Effect and the Eight Other Business Delusions That Deceive Managers. New York: Free Press.

- Rother, M. and Aulinger, G. (2017). Toyota Kata Culture: Building Organizational Capability and Mindset Through Kata Coaching. New York: McGraw Hill Professional.

- Rother, M. (2010). Toyota Kata: Managing People for Improvement, Adaptiveness, and Superior Results. New York: McGraw-Hill Professional.

- Kirkpatrick, S. A. and E. A. Locke. (1991). "Leadership: Do Traits Matter". Academy of Management Executive, 5.

- Seddon, J. (2003). Freedom from Command and Control: A Better Way to Make the Work, Work. Buckingham: Vanguard Education.

- Shook, J. (2010). "How to Change a Culture: Lessons From NUMMI", MIT Sloan Management Review, 51.

- Hammond, Sue. A. (1998). The Thin Book of Appreciative Inquiry. Thin Boob Publishing Co.

- Van Vugt, M. and Ahuja, A. (2010). Selected: Why Some People Lead, Why Others Follow, and Why It Matters. London: Profile Books.

- Vera, D. and Crossan, M. (2004). "Strategic Leadership and Organisational Learning", Academy of Management Review, 29, 222-240.

- Weisbord, M. R. (1976). “Organizational Diagnosis: Six Places to Look for Trouble With or Without a Theory", Group \& Organization Studies, 1 (4), pp. 430-447.

- Wheatley, M. J. (2005). Finding Our Way: Leadership For an Uncertain Time. San Francisco, CA: Berrett-Koehler Publishers. 
